\title{
STUDI PENDAHULUAN STREETSCAPE YANG MERESPON BENCANA
}

\author{
Bangun I.R. Harsritanto*) Totok Roesmanto*) \\ *)Departemen Arsitektur, Fakultas Teknik, Universitas Diponegor, Semarang, Indonesia
}

\begin{abstract}
Semarang seperti kota-kota besar lainnya di Indonesia menghadapi bencana alam maupun bencana akibat kelalaian manusia seperti : banjir, longsor, dan kebakaran. Streetscape sebagai unsur dari jalur transportasi dan mitigasi bencana perlu pendekatan desain khusus untuk memenuhi fungsi aksesibilitas universalnya meskipun dalam keadaan bencana. Beberapa kasus yang terjadi adalah sebaliknya. Ketika bencana itu terjadi streetscape menjadi tidak berfungsi dan bahkan memperparah dampak bencana tersebut, Tujuan: Tujuan dari studi ini adalah untuk merumuskan desain streetscape yang merespon bencana yang terjadi di Semarang (terutama : banjir, longsor dan kebakaran). Metode: Desain penelitian ini adalah eksploratif dengan merespon hasil observasi evaluasi kawasan terutama yang sering terkena bencana (studi kasus). Streetscape yang akan diobservasi dan dijadikan studi kasus. Desain streetscape harus mampu mengalirkan air secara khusus, membendung longsoran tanah maupun memutus kobaran api yang dapat menghancurkan area perkotaan.Untuk penelitian lanjutan dapat dilakukan evaluasi pada streetscape yang ada pada perumahan atau permukiman dengan variable maupun parameter yang disebut diatas
\end{abstract}

Keywords: communal space; old city; adaptability; transform

\section{Latar Belakang}

Indonesia menurut data Persatuan BangsaBangsa (PBB) tahun 2014 menempati posisi 38 dalam negara di dunia yang tinggi risiko mengalami bencana. Menurut Bank Dunia, bencana-bencana itu menyebabkan Indonesia kehilangan sekitar 500 Juta Dollar tiap tahun dan akan bertambah menjadi sekitar 800 juta Dollar pada 10 tahun ke depan jika tidak mulai mempersiapkan penanganan bencana ini.

Bencana dapat dibagi menjadi dua : bencana alam dan bencana karena kelalaian manusia. Bencana alam di Indonesia sendiri menurut Office of Coordination of Humanitarian Assistence menjadi bagian yang tidak terpisahkan karena posisi geografis dan geologis Indonesia yang sangat berisiko (lihat gambar 1)

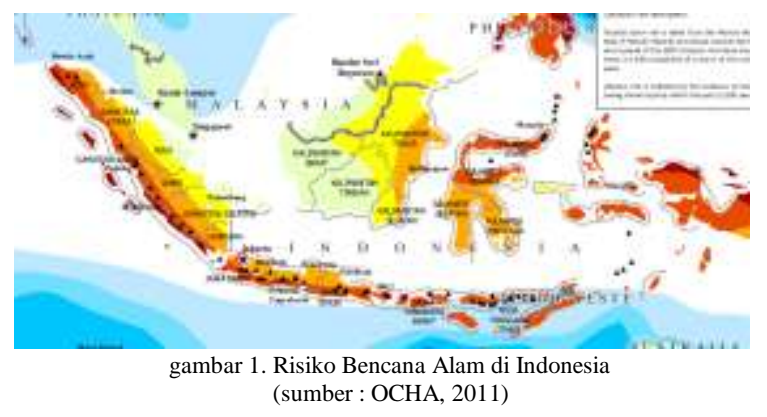

Semarang seperti kota-kota besar lainnya di Indonesia menghadapi bencana alam maupun bencana akibat kelalaian manusia seperti : banjir, longsor ,dan kebakaran.

Streetscape sebagai unsur dari jalur transportasi dan mitigasi bencana perlu pendekatan desain khusus untuk memenuhi fungsi aksesibilitasnya. Dalam menjalankan fungsi sebagai sarana umum streetscape seharusnya mampu secara universal di gunakan oleh semua warga apapun kondisi fisiknya dan kapanpun bahkan dalam keadaan bencana. Beberapa kasus yang terjadi adalah sebaliknya. Ketika bencana itu terjadi streetscape menjadi tidak berfungsi dan bahkan memperparah dampak bencana tersebut, Seperti contoh kasus jika banjir maka streetscape menjadi bagian dari kubangan besar yang tidak jelas batasnya sehingga tidak aksesibel, ataupun ketika ada kebakaran streetscape tidak mendukung akses pemadaman kebakaran karena tidak dapat dilalui korban kebakaran maupun oleh mobil pemadam.

Tujuan Penelitian ini untuk mengidentifikasi bencana kawasan, evaluasi keadaan streetscape terkait bencana lingkungan, eksporasi desain streetscape yang merespon bencana

Urgensi penelitian ini adalah menurut data $\mathrm{BNPB}(2015)$ frekuensi laporan bencana banjir adalah 45\% dari keseluruhan bencana alam dan bencana kedua yang dilanda semua wilayah Indonesia yang 
mengakibatkan : 396km jalan rusak. Semarang terkenal dengan banjirnya sehingga perlu segera menemukan desain yang responsif, memanfaatkan potensi dan meminimalkan risiko dari bencana ini.

Longsor merupakan bencana yang terkait dekat dengan banjir dengan persebaran risikonya pada semua pulau di Indonesia terutama Jawa yang sudah berkurang kekerasan tanahnya.

Terbentuknya Badan Nasional Penanggulangan Bencana yang bersifat preventif dan kuratif tetapi belum merespon potensi dan masalah dari bencana dengan desain streetscape yang akan selalu digunakan oleh tiap penduduk

\section{Kebencanaan}

Bencana lingkungan dibagi menjadi dua : bencana alam dan bencana akibat kelalaian manusia. Menurut BNPB (2015) bencana akibat kelalaian manusia adalah : kebakaran dan konflik sosial sedangkan bencana alam di Indonesia dapat digolongkan menjadi :

1.Gempa

2.Tsunami

3.Gunung Meletus

4.Banjir

5.Topan Badai

6.Longsor

7.Kemarau

BNPB juga mencatat bahwa banjir dan longsor sebagai bencana ikutannya adalah bencana alam yang paling merata terjadi di Indonesia. Kedua bencana itu terjadi hampir pada tiap tahun saat musim penghujan sekitar November-maret, sehingga perlu penanganan khusus untuk menanggulangi keterulangannya.

Menurut Indonesia Disaster Management Handbook (2015) Faktor yang menyebabkan banjir adalah : tidak baiknya drainase kawasan, deforestasi di hulu sungai, sedimentasi dan penutupan luasan tanah dengan bangunan.

Sedangkan kebakaran sebagai bagian dari bencana kelalaian manusia, diakibatkan oleh : hubungan singkat listrik dan panas lingkungan yang tidak terkontrol.

\section{Streetscape}

Menurut Kostoff (1992) Streetscape adalah jalur untuk pedestrian dan bangunan yang membatasinya. Sedangkan menurut kamus Oxford, streetscape adalah bidang jalan yang membentang diantara dua destinasi rumah (termasuk jalur pejalan kaki dan kendaraan). Dari kedua definisi tersebut dapat simpulkan bahwa streetscape adalah jalan yang berada di antara bangunan yang dapat digunkana oleh pejalan kaki maupun kendaraan.

Menurut Islington (2005) streetscape seharusnya didesain dengan mempertimbangkan banyak hal tidak hanya fisik tetapi juga terkait sosial, ekonomi dan budaya, seperti kaidah :

1. Material pembentuknya yang minimal

2. Perletakan furnitur jalan

3. Konsistensi dan keselarasan desain dengan lingkungan

4. Penggunaan karakter lokal

5. Memperhatikan keamanan dan keselamatan penggunaan

6. Integrasi semua elemen jalan

7. Dapat diakses semua orang

8. Memperhatikan aspek pemeliharaan

9. Mematuhi peraturan setempat

Dari kesembilan kriteria tersebut secara implisit dapat digarisbawahi kata-kata yang menyebutkan akses untuk semua selaras dan memperhatikan kondisi lingkungan setempat sehingga perlu adanya studi khusus tentang masalah dan potensi sekitar dalam mendesain streetscape yang baik.

\section{Respon Bencana}

Dalam mempertimbangkan masalah dan potensi lingkungan perlu juga memperhatikan bencana yang sering terjadi, sehingga yang keluar adalah desain yang merespon juga bencana.

Terkait respon terhadap bencana, streetscape menjadi jalur yang menyediakan beberapa aktivitas seperti : evakuasi korban, drainase kawasan, sirkulasi kendaraan, hingga mendukung pemadaman kebakaran. Dalam mengevakuasi korban terdapat aspek yang perlu diperhatikan (NFPA,2007) yaitu : rute evakuasi, area berkumpul, wayfinding yang dapat diakses oleh semua manusia tanpa membedakan gender, usia, kemampuan. Sedangkan dalam drainase kawasan perlu memperhatikan proses pengaliran air maupun material lain dari tempat yang tinggi ke rendah. Sirkulasi kendaraan perlu diperhitungkan karena keberadaan jalan tidak hanya digunakan oleh pejalan kaki tetapi juga pengguna kendaraan. Terakhir respon bencana juga dapat diidentifikasi dengan keberadaan furniture maupun fasilitas pendukung pemadaman kebakaran

\section{Metode Penelitian}

Desain penelitian ini adalah eksploratif dengan merespon hasil observasi dan evaluasi kawasan terutama yang sering terkena bencana (studi kasus) Kegiatan ini akan dilakukan selama 8 minggu. Streetscape yang akan diobservasi dan dijadikan studi kasus dengan table evaluasi yang disusun peneliti berdasarkan teori universal desain dan evakuasi bencana.

Data akan dianalisis menggunakan pendekatan deskriptif yang selanjutnya akan dilakukan studi penerapan desain yang dapat digunakan oleh semua orang untuk streetscape tersebut. 
Lokasi dari penelitian ini berada di Semarang dan untuk bencana yang terpilih adalah : banjir, longsor, kebakaran.

\section{Respon Streetscape terhadap bencana banjir}

Semarang sebagai kota besar memiliki paparan bencana banjir yang cukup luas dan dominan (lebih dari $50 \%$ ) dapat dilihat pada figure2. Kondisi tersebut diduga karena tiga sebab :

(1) Banjir lokal merupakan banjir yang terjadi karena minimnya jumlah dan kualitas sistem drainase di daerah permukiman terutama di kawasan dataran rendah dan pesisir Kota Semarang;

(2) Banjir kiriman adalah aliran banjir yang datang dari arah hulu, akibat hujan dengan intensitas tinggi sehingga menimbulkan aliran yang melebihi kapasitas sungai, dan menggenangi kawasan yang berada di hilir sungai; dan

(3) Banjir rob adalah banjir yang terjadi akibat aliran langsung air pasang dan/atau aliran balik dari saluran drainase akibat terhambat oleh air pasang (Wismarini \& Ningsih, 2010)

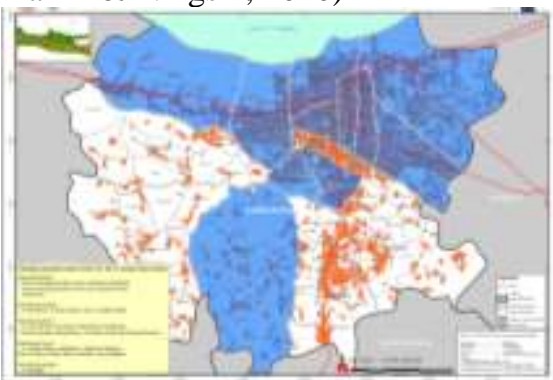

Figure 2. Peta Bencana Banjir Semarang (BNPB,2009)

Menurut Rissa \& Syariffudin (2015) kesiapan terhadap bencana banjir tersebut tergantung pada :

1.Kondisi drainase lingkungan

2.Koefisien Dasar Bangunan (KDB)

3.Kondisi kesejahteraan penduduk

Kondisi Koefisien Dasar Bangunan di Semarang termasuk yang cukup memprihatinkan dengan dominasi KDB rumah di atas $60 \%$ yang mendekati angka absolute. Hal tersebut juga diperparah dengan ketidak siapan kondisi streetscape perumahan yang tidak dilengkapi dengan prasarana drainase yang memadai (lihat figure 3)yang mengakibatkan air tidak dapat mengalir dengan lancar melalui saluran khusus tetapi juga menggunakan badan jalan. Sehingga streetscape yang ada harus menanggung perjalanan : manusia, kendaraan, air dan sampah yang ada (prinsip equirable in use).

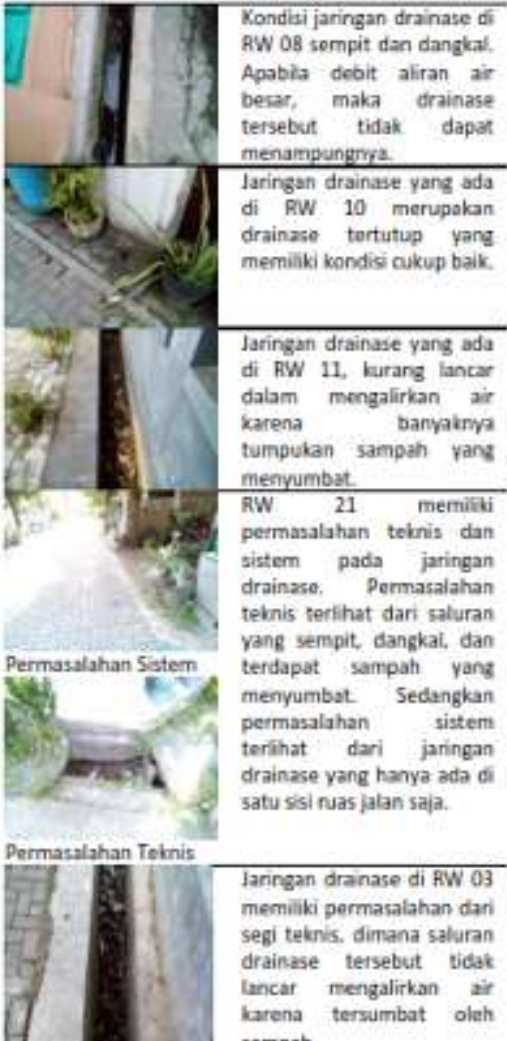

Figure 3. Kondisi drainase streetscape (Rissa \& Syarifudin, 2015)

Kondisi ideal dari streetscape yang merespon banjir adalah menghadirkan gutter (batas pinggir/selokan air) untuk mengalirkan air pada satu atau dua sisi streetscape dengan menghantarkan resapan di tempat pohon/vegetasi yang dapat menjadi peneduh jalan (lihat figure 4).

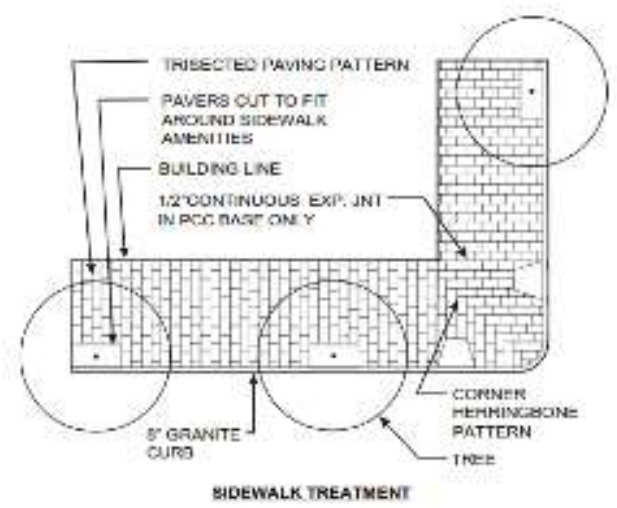

Figure 4. Streetscape yang merespon aliran air( DC Government, 2010)

Respon pengaliran air yang tidak sebidang dengan pengguna jalan lain dan peresapan pada tiap jarak tertentu dapat menjadi solusi respon terhadap banjir yang sering melanda di Semarang (prinsip tolerance in error). 


\section{Respon Streetscape terhadap bencana longsor}

Tanah dan batuan merupakan material utama pada tanah longsor. Kondisi dari material tanah dan batuan yang menyusun sebuah lereng dapat dijadikan parameter terjadinya longsor. Berdasakan peta jenis tanah yang diperoleh dari BAPPEDA Semarang, daerah penelitian tersusun atas empat jenis tanah yaitu Komplek Andosol Kelabu Tua, Litosol Coklat Kemerahan, Latosol Merah Kuning dan Coklat Tua, dan Aluvial Coklat Tua.

Sedangkan indikator dari pengelolaan lahan adalah pola tanam vegetasi, pemotongan dan penggalian lereng, pembangunan konstruksi, pencetakan kolam dan pembangunan drainase lereng dengan beberapa kelas (lihat figure 5)

\begin{tabular}{|c|c|c|c|}
\hline No & Kelas & $\begin{array}{c}\text { Kemiringan } \\
\text { Lereng }(\%)\end{array}$ & Derajat $\left({ }^{\circ}\right)$ \\
\hline I & I & $0-8$ & $0-5$ \\
\hline 2 & II & $9-15$ & $5-7.5$ \\
\hline 3 & III & $16-20$ & $7,5-11$ \\
\hline 4 & IV & $21-30$ & $11-16$ \\
\hline 5 & V & $31-35$ & $16-18,5$ \\
\hline 6 & VI & $36-40$ & $18,5-21$ \\
\hline 7 & VII & 40 & $>21$ \\
\hline
\end{tabular}

Figure 5. Kelas Kemiringan Tanah (DEM Jawa Tengah)

Kota Semarang memiliki 2 bagian kota yang berada di bawah dan atas sehingga dapat dikatakan memiliki bukit berlereng yang cukup banyak. Beberapa diantara lereng tersebut dapat berpotensi menjadi rawan longsor secara alami (geologis) maupun karena pengelolaan lahan yang tidak sesuai (human error).

Pada figure 6 dapat dijelaskan kondisi akibat pengelolaan lahan yang tidak sesuai yang mengakibatkan kondisi lereng menjadi curam setelah dikeruk atau dikepras untuk lokasi bangunan atau hanya diambil tanahnya saja.

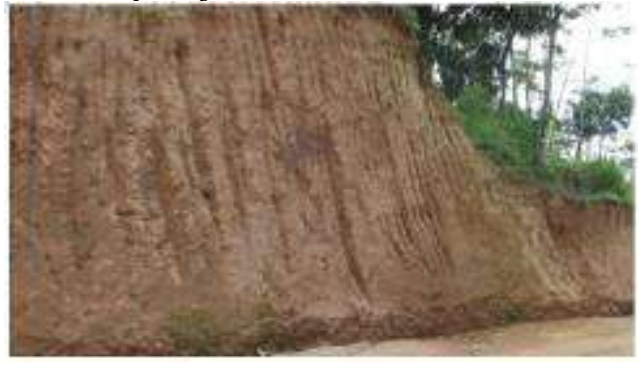

Figure 6. Kondisi Lereng Curam (Sriyono,2012)

Penanaman vegetasi dapat menjadi salah satu solusi alami selain pembuatan dinding penahan longsor dan jaringan drainase yang biasa diterapkan pada bangunan atau jalan yang memiliki batas lereng yang cukup curam (Sriyono, 2012) .
Daerah yang berpotensi longsor seperti yang disebut di atas perlu adanya :

1. Penguatan tanah dan batuan secara alami Jenis tanaman yang disarankan oleh Bank Dunia pada kawasan lindung atau kawasan rawan bencana longsor yaitu akasia, pinus, mahoni, johar, jati, kemiri, dan damar. Khusus untuk daerah berlereng curam di lembah dapat ditanami bambu (Sitorus, S.R.P., 2006). Sementara pola penanaman yang dapat dikembangkan pada daerah lereng pegunungan dan tebing yaitu tanaman berakar dalam, bertajuk ringan, cabang mudah tumbuh dan mudah dipangkas (misalnya lamtoro, pete, sonokeling, dan kaliandra), untuk di kaki lereng atau di kaki bukit (mahoni), dan untuk daerah lembah dengan tanaman bambu (Sujoko dalam Karnawati, 2006). Untuk dapat menguatkan tanah pada lereng diantaranya adalah pohon kemiri, laban, dlingsem, mindi, johar, bungur, banyan, mahoni, renghas, jati, kosambi, sonokeling, trengguli, tayuman, asam jawa dan pilang (Fakultas Kehutanan Universitas Gajah Mada, 2001).

2. Pemantapan lereng

Pemantapan lereng atau dinding penahan longsor memiliki (prinsip safety)persyaratan keamanan sebagai berikut :

\begin{tabular}{|c|c|c|c|c|c|}
\hline \multirow{3}{*}{ 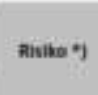 } & \multirow{3}{*}{ Kandisi Beban } & \multicolumn{4}{|c|}{ Purameter Kuat Geser $*$ ) } \\
\hline & & \multicolumn{2}{|c|}{ Makoimus } & \multicolumn{2}{|r|}{$\operatorname{sen}$} \\
\hline & & Telan & Kurang Teali & Telin & Turans Teini \\
\hline \multirow{2}{*}{ Tinsel } & Dengan Uempa & 1,50 & 175 & 1.35 & 1,50 \\
\hline & Taros Gempa & 1.80 & 2,00 & 1.60 & 1.80 \\
\hline \multirow{2}{*}{ Menengah } & Dengan Gempa & 1,30 & 1,60 & 1,20 & 1,40 \\
\hline & Tetrpa Getmpa & 5.50 & 1.80 & 135 & 150 \\
\hline \multirow{2}{*}{ Alendah } & Derean Gempa & 2,10 & 1,25 & 1.00 & 1,10 \\
\hline & Tanga cempa & 1.25 & 1,40 & 110 & 1.20 \\
\hline
\end{tabular}

Figure 7. Faktor Keamanan Lereng (KepMen PU no.378/KPTS/1987)

\section{Drainase}

Sistem drainase menurut Sriyono (2012) merupakan kunci dalam pemanfaatan lahan yang berpotensi longsor. Hal tersebut dikuatkan oleh Marsh (1991) yang memasukan drainase dalam kemiringan lereng rawan longsor. Selain itu pengupasan material dapat memperkecil beban pada lereng, yang berarti meminimalkan besarnya gaya penggerak pada lereng, dan efektif diterapkan pada lereng yang lebih curam dari $40 \%$.

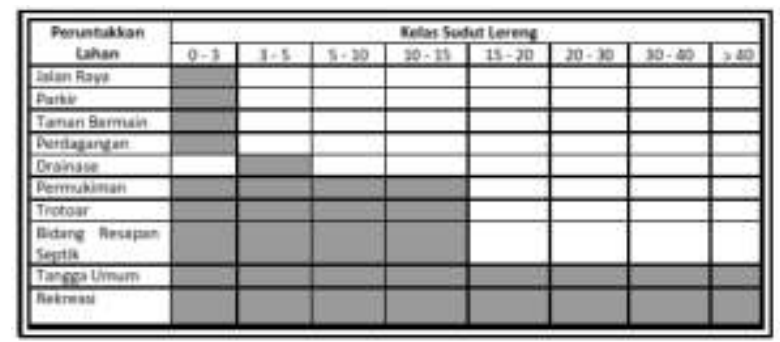

Figure 8. Kesesuaian Lahan Berdasar Kemiringan Lereng (Marsh, 1991) 


\section{Respon Streetscape terhadap bencana kebakaran}

Kebakaran adalah reaksi dari oksigen yang terpapar energi panas yang berlebihan. Sehingga unsur dari kebakaran adalah :

1. Oksigen

2. Panas

3. Bahan Bakar

Tahapan Kebakaran Dalam Ruangan

Pada umumnya kebakaran dalam ruangan dengan terbagi dalam tiga tahapan. Masing-masing tahapan memiliki ciri-ciri karaktersitik dan efeknya berhubungan dengan bahan yang terbakar yang berbeda-beda. Lama dari masing-masing tahapan bervariasi tergantung keadaan dari penyulutan, bahan bakar, dan ventilasi, akan tetapi secara keseluruhan tahapannya adalah kebakaran awal kebakaran bebas kebakaran menyurut.

1. Kebakaran Tahap Awal

2. Penyalaan Bebas

3. Api Mengecil

Dari 3 unsur dan tiga tahap kebakaran dalam ruang tadi, di Semarang mayoritas penyebabnya adalah hubungan arus pendek kelistrikan pada daerah perumahan (lihat figure 9 dan 10). Sehingga dapat direspon dengan streetscape yang mengurangi kontak oksigen, panas berlebihan dan bahan bakar dan apabila terjadi kebakaran dapat segera di potong segitiga kebakarannya sehingga api tidak menjadi bebas setelah tahap awal dan segera mengecil.

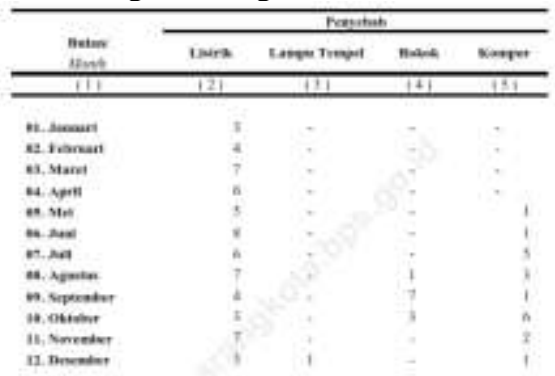

Figure 9. Penyebab Kebakaran (Semarang Dalam Angka 2015)

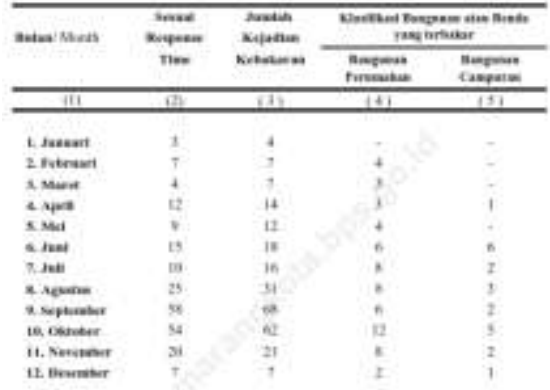

Figure 10. Jumlah kejadian dan Jenis Bangunan yang Terbakar (Semarang dalam Angka 2015)
Kriteria mitigasi dan pemutusan tiga unsur kebakaran secara cepat menjadi respon utama dalam desain streetscapenya. Unsur mengurangi panas berlebih dapat di respon dengan penanaman vegetasi, dan pemutusan akses bahan bakar dapat dilakukan dengan pembuatan saluran antara bangunan dan jalan. Sedangkan memutus oksigen secara desain alamiah (pasif) dapat dikatakan tidak mungkin karena manusia membutuhkan oksigen untuk bernafas demi kehidupannya

\section{Evaluasi terhadap streetscape terpilih}

Streetscape yang dievaluasi adalah streetscape di area permukiman yang beragam tipenya. Sehingga untuk kelanjutan dari penelitian ini perlu adanya investigasi dan penilaian terhadap streetscape di area perumahan atau permukiman penduduk yang rawan terhadap bencana banjir, longsor dan kebakaran, sesuai temuan dari penelitian awal ini.

Penilaian sendiri dapat dilakukan dengan sistem kuesioner terbuka dengan random stratified sample untuk memudahkan penganalisaan data yang akan diolah,. Nilai dari tiap streetscape memiliki rentang 1-5 sesuai perkiraan dan opini pengisi kuesioner.

\section{Kesimpulan}

Streetscape sebagai salah satu elemen kota menjadi salah satu upaya awal untuk menanggulangi bencana alam yang menimpa suatu daerah. Desain streetscape harus mampu mengalirkan air secara khusus, membendung longsoran tanah maupun memutus kobaran api yang dapat menghancurkan area perkotaan.

Untuk penelitian lanjutan dapat dilakukan evaluasi pada streetscape yang ada pada perumahan atau permukiman dengan variable maupun parameter yang disebut diatas. Menggunakan 5 skala untuk penilaian dan pemaknaannya

\section{Persembahan}

Penulis berterimakasih atas pendanaan penelitian Departemen Arsitektur Fakultas Teknik Universitas Diponegoro 2017 yang telah mendukung publikasi ini.

\section{Daftar Pustaka}

Arikunto, S. (2002). Prosedur Penelitian: Suatu Pendekatan Praktek. Edisi V. Jakarta: Rineka Cipta

Arnold R. Spokane, Joanna L. Lombard , Frank Martinez, Craig A. Mason, Deborah GormanSmith ,Elizabeth Plater-Zyberk, Scott C. Brown, Tatiana Perrino \& José Szapocznik (2007) Identifying Streetscape Features Significant to Well-Being, Architectural Science Review, 50:3, 234-245

BPS Semarang (2015) Semarang dalam Angka 2015 
Center for Excellence in Disaster Management \& Humanitarian Assistance (2015) Indonesia Disaster Management Reference Handbook, Hornet Ave (accessed at (http://www.cfedmha.org)

Depertemen Pekerjaan Umum. 2007. Pedoman penataan Ruang Kawasan Rawan Bencana Longsor. Jakarta: Depertemen Pekerjaan Umum

Eric Dumbaugh \& J. L. Gattis (2005) Safe Streets, Livable Streets, Journal of the American Planning Association, 71:3, 283-300

Government of DC (2000) Downtown Streetscape Regulation s, Dpeartment of Public Works

Harsritanto IR Bangun(2017) Urban Environment Development based on Universal Design Principles, ICENIS 2017 proceeding

Kostoff (1992) The City Assembled the Element of Urban Form Through History, Thames\& Hudson. London

Indrakusumo, Bangun 2016 Design Characteristics of Specialized Streets for Indonesia through Cases of South Korea Doctoral's thesis, Pukyong National University, South Korea

Islington Council, (2005) IslingtonStreetbookA borough-wide streetscape manual,Islington Council London

Molly Follette Story M.S. (1998) Maximizing Usability: The Principles of Universal Design, AssistiveTechnology: The Official Journal of RESNA, 10:1, 4-12

NFPA (2007) Emergency Evacuation Planning Guide for Person with Disabilities, National Fire Protection Association

North Caroline State University, College of Design 1997. The Center For Universal Design, Retrieved $21 \quad$ May 2010 from http://www.design.ncsu.edu/cud

Rawiwan Oranratmanee \& Veera Sachakul (2014) Streets as Public Spaces in Southeast Asia: Case Studies of Thai Pedestrian Streets, Journal of Urban Design, 19:2, 211-229

Rizsa Putri Danianti dan Sariffuddin (2015) Tingkat Kerentanan Masyarakat Terhadap Bencana Banjir Di Perumnas Tlogosari, Kota Semarang, Jurnal Pengembangan Kota vol 32 (http://ejournal2.undip.ac.id/index.php/jpk)

Sriyono, Agus (2012) Identifikasi kawasan rawan bencana longsor Kecamatan banyubiru, kabupaten semarang, skripsi Universitas Negeri Semarang

Sanoff, H (1991) Visual Research Methods in Design, Van Nostrand Reinhold, Newyork

Wismarini, T. D., \& Ningsih, D. H. U. (2010). Analisis Sistem Drainase Kota Semarang Berbasis Sistem Informasi Geografi dalam Membantu
Pengambilan Keputusan bagi Penanganan Banjir. Dinamik-Jurnal Teknologi Informasi 15

Zheng Wei (2012) Fire Safety Design of Indoor Pedestrian Streets of Large c ommercial Building, Procedia Engineering 52 ( 2013 ) 652 656

Website

BMKG , CAP in BMKG Planning and its Implementation. April 2013. https://www.wmo.int/pages/prog/amp/pwsp/docu ments/CAP-IW-2013-p03-19-ID-BMKG.ppt

ForUm, The Effects of Natural Hazards:Migration and Dynamics of Development in Medan City. http://www.forumurbanfutures.net/activities/papers/effectsnaturalhazards-(tsunami-disaster)\%3Amigrationand-dynamics-development-med

KepMen PU no.378/KPTS/1987

Permen PUI no. 22/PRT?M/2007 Pedoman Penataan Ruang Kawasan Rawan Longsor

PP No 21 of 2008 Concerning Disaster Management, BNBP.

PP No 21 of 2008 Concerning Disaster Management, BNBP

PP No 23 of 2008 Concerning Participation of International Institutions and Foreign NonGovernmental Organizations in Disaster Management ,BNBP

Relief Web, Flood-monitoring website : launched. December 3, 2014. http://reliefweb.int/report/indonesia/floodmonitor ing-website-launched

The World Bank, The Rise of Metropolitan Regions: Towards Inclusive and Sustainable Regional Development. August 13 , 2012.(http://www.worldbank.org/en/news/ feature/2012/08/13/towards-inclusiveandsustainable-regional-development) 